\title{
独立状態の吊橋主塔の渦励振に関する実験的研究 EXPERIMENTAL STUDY ON VORTEX-EXCITED OSCILLATION OF SUSPENSION BRIDGE TOWERS IN FREE-STANDING
}

\author{
松 崎 実*.牛 尾 正 之** ・南 條 正 洋*** \\ By Minoru MATSUZAKI, Masayuki USHIO and Masahiro NANJO
}

\section{1. 緒言}

自然風の中に設置された構造物には，静的な風荷重が 作用するとともにその構造特性によっては風による各種 の動的な影響む現われる．特に，吊橋・斜張橋・塔状構 造物のようにフレキシブルな構造物は動的荷重に敏感な ため, 風による振動現象に対して十分な配慮が必要とさ れる.

吊橋主塔もケーブル架設前の独立状態では橋軸方向に かなりフレキシブルな構造となるため, 風による振動が 生じやすいが，その場合によくみられる振動現象は，後 流中に発生する交番渦などに起因する渦励振である.こ れは，風向直角に振動する現象であり，固有振動数が低 いと発現風速はかなり低くなる．従来の実物観測あるい は風洞実験結果によると, 渦励振現象は, ある狭い風速 範囲で生じ，かつ振幅む限定された振動であり，ただち に構造強度に致命的な影響を与えることはほとんどない ようである. しかし，架設工事に対して各種の支障を及 ぼし，かつ振幅が大きくなる場合には主塔自体に局部的 な損傷を与える可能性もあり，何らかの制振対策が必要 となることが多い.

この種の振動現象が最初に注目されたケースは, 1964 年に完成したイギリスの Forth 道路橋の主塔であった. ここでは，主塔の架設中に橋軸直角方向からの約 $9 \mathrm{~m} / \mathrm{s}$ の風によって, 橋軸方向の振動が発生し, $147.8 \mathrm{~m}$ の塔 頂で約 $1 \mathrm{~m}$ の振幅が観測された より斜めに 2 本のロープを張り，その下端に取り付けた $15 \mathrm{tf}(15 \mathrm{t})$ のコンクリート・ブロックを $45^{\circ}$ に傾斜し たコンクリートの滑り台上に設置して, 摩擦減衰を付加 する対策によって効果をあげたとのことである.また，

* 正会員 本州四国連絡橋公団第三建設局

** 正会員 工博 日立造船 (株) 技術研究所

*** 正会員 工修 日立造船 (株) 技術研究所
1966 年に完成したイギリスの Severn 橋では, Forth 道 路橋の経験を参照して, 主塔の $1 / 55$ 全体模型によりあ らかじめ風洞実験を実施した。 その実験で，Forth 道路 橋の主塔でみられた振動と同様の現象が観察されている が，塔頂部付近の両柱間に高さ $18 \mathrm{~m}$ の仕切板を取り付 けると制振効果があがることを確認し，この方法を架設 工事に適用した ${ }^{2)}$. わが国では，1973 年に完成した関門 橋の架設に際して，主塔の耐風性が風洞実験によって検 討された ${ }^{3)}$. その結果構造対数減衰率を 0.026 とした場 合, $13 \mathrm{~m} / \mathrm{s}$ 前後の風速で, 塔頂における 最大振幅が約 $0.5 \mathrm{~m}$ になることが推定され，これを抑制する対策とし て, Forth 道路橋の場合と同様のスライディング・ブロ ックが設置されている゙).このような実例を参考として, 因島大橋の主塔に対しても，現地の諸条件を考慮し， Forth 橋や関門橋で用いられたスライディング・ブロッ ク方式と，ブロックの代わりに油圧ダンパーおよび重錘 を組み合わせたシステム ${ }^{5), 6)}$ を取り付けて付加減衰力を 調整する方式の振動抑制対策が主塔独立時に施された.

ところで, これまで, 主塔の耐風性を検討するための 風洞試験はいろいろと実施されているが，それに対応寸 る実物の 自然風下での精密な 観測データはほとんどな く, したがって, 各種の制振装置の効果はまだ必ずしも 明らかではないのが現状である.このような背景のもと で，著者らは，因島大橋の建設現地において，独立状態 の主塔を対象に，塔頂部での自然風や主塔の各種振動現 象を測定する 機会を得た. 実測期間は，1979 年 9 月か ら 1980 年 4 月までであったが，この間，秋の台風，冬 の季節風さらには春の大型低気圧の通過など種々の強風 に遭遇し，スライディング・ブロック方式を採用した主 塔では，制振装置を付けない場合および付けた場合にお ける風速と振幅の記録を採取することができた. 一方, これらの現地計測と並行して，現地で観測された振動現 象の究明を目的として, 1/100 縮尺模型による風洞実験 も実施した. この風洞実験では，通常の一様流および格 
子による乱流のもとで, 主塔模型に生じる振動現象を測 定している.

本論文は，以上述べた現地観測と風洞実験で得られた 結果を述べるものであるが，前述のごとく，風洞実験結 果と実構造物の挙動の関連性に関する資料が不足してい る現状において, これらの結果は構造物の耐風設計法の 合理化に対する一つの基礎資料になろらと考えるもので ある7?.

\section{2. 因島大橋主塔の現地計測}

\section{（1）因島大橋主塔と制振装置の概要}

本州四国連絡橋因島大橋は，向島と因島の間を結ぶ地 点に架設される 3 径間 2 ヒンジ吊橋であって, 中央径間 $770 \mathrm{~m}$ ，側径間 $250 \mathrm{~m}$ の規模を有する.この吊橋の主塔 の一般形状および断面 形状を図一1 に示す. 本橋の主塔の架設段階 における渦励振対策と しては，前に述べたよ うに因島側の主塔（以 後 $3 \mathrm{P}$ と称する) では スライディング・ブロ ック方式, 向島側の主 塔(以後 $2 \mathrm{P}$ と称する)

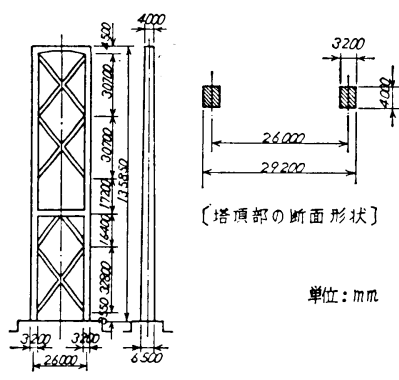

図一1 因岛大橋主塔一般図 ではダンパ重鍾方式が採用された. 図一2には，スライ ディング・ブロック方式の制振装置の設置要領を示す.

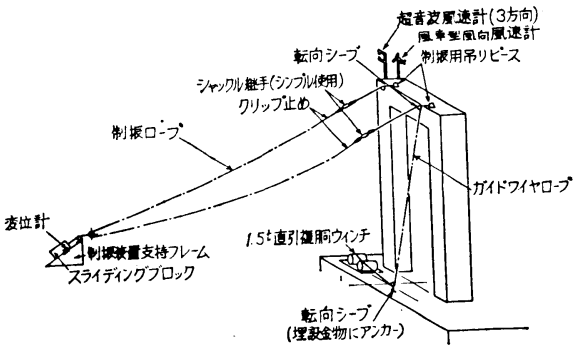

図一2 制振装羁の設置要領

\section{（2）計測方法}

現地計測では, (1) 風速, (2) 塔の振動, (3) スライディ ング・ブロックの変位の各計測を行った. 風速は, ケー ブル・サドルの天端より約 $2 \mathrm{~m}$ 上空に超音波風速計 (3 方向）および風車型風向風速計各 1 台を設置して測定し た. (2) の主塔の振動計測では, 塔頂部および 塔内の各 部に 6 台のサーボ型加速度計を設置して橋軸方向の水平 振動を検出した. また，(3) のスライディング・ブロッ クの変位は, すべり台とスライディング・ブロックの相
表一1 因岛大橋主塔の現地計測結果の代表例

\begin{tabular}{|c|c|c|c|c|c|c|}
\hline RUN & $\begin{array}{l}\text { 测定日 } \\
{\left[\begin{array}{l}\text { 年] } \\
\text { 月 }\end{array}\right.}\end{array}$ & $\begin{array}{l}\text { 平均 } \\
\text { 風速 } \\
(\mathrm{m} / \mathrm{s})\end{array}$ & $\begin{array}{l}\text { 平均 } \\
\text { 風向 } \\
\text { (deg) }\end{array}$ & $\begin{array}{l}\text { 塔 頂 } \\
\text { 最大片 } \\
\text { 幅 } \\
(\mathrm{cm})\end{array}$ & $\begin{array}{l}\text { 制振装置* } \\
\text { の 状 況 }\end{array}$ & 備 \\
\hline 704 & $\begin{array}{r}{[1979]} \\
9.30\end{array}$ & 22.7 & 306 & 10.9 & フリー状態 & \multirow[t]{2}{*}{ 台風 7916 号 } \\
\hline 1012 & 10.7 & 8.9 & 283 & 8.3 & $W=2.25 \mathrm{tf}$ & \\
\hline 1603 & 10.19 & 17.8 & 283 & 10.6 & " & \multirow{4}{*}{$\begin{array}{c}\text { 台風 } 7920 \text { 号 } \\
\left\{\begin{array}{l}\text { 顕著な渦励振 } \\
{\left[\begin{array}{c}\text { 乱れ強さ17\%] }\end{array}\right.}\end{array}\right.\end{array}$} \\
\hline 2201 & 10.21 & 8.6 & 259 & 6.7 & $"$ & \\
\hline 2501 & 11.13 & 11.2 & 263 & 37.4 & " & \\
\hline 3208 & $\begin{array}{r}12.25 \\
{[1980]}\end{array}$ & 11.1 & 263 & 19.9 & $"$ & \\
\hline 3308 & 1.5 & 12.3 & 281 & 12.3 & $"$ & \multirow{4}{*}{ 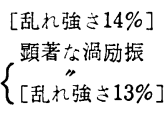 } \\
\hline 3408 & 1.17 & 10.5 & 256 & 39.6 & " & \\
\hline 3507 & 1.17 & 12.1 & 277 & 34.1 & " & \\
\hline 3707 & 1.21 & 12.9 & 245 & 6.5 & $"$ & \\
\hline 3802 & 1.24 & 8.2 & 269 & 9.5 & " & \multirow{4}{*}{$\begin{array}{l}\text { 顕著な渦励振 } \\
{[\text { 乱れ強き15\%] }}\end{array}$} \\
\hline 3904 & 1.30 & 9.2 & 268 & 16.5 & $"$ & \\
\hline 4602 & 2.13 & 10.0 & 266 & 30.6 & " & \\
\hline 4904 & 2.21 & 10.9 & 68 & 9.9 & フリー状態 & \\
\hline $5302^{* *}$ & 3.1 & 9.5 & 270 & 77.0 & $\Rightarrow$ & \multirow{2}{*}{$\begin{array}{c}\text { 顕著な渦励搰 } \\
\text { " }\end{array}$} \\
\hline $5304^{* *}$ & 3.1 & 10.0 & 273 & 43.0 & $W=2.25 \mathrm{tf}$ & \\
\hline $5305^{* *}$ & 3.1 & 9.5 & 270 & 40.6 & $"$ & $"$ \\
\hline $5403^{* * *}$ & 3.24 & - & - & 16.4 & $W=5.58 \mathrm{tf}$ & \\
\hline $5404^{* * *}$ & 3.26 & - & - & 9.3 & $"$ & \\
\hline $5406^{* * *}$ & 4.1 & - & - & 15.6 & " & \\
\hline
\end{tabular}

*Wは制振装置のスライディンク・ブロックの重量, 詳細は表一3 参照.

**超音波風速計のデータなし（風車型風向風速計の記録より判断）. ***風速データなし。

対変位を差動トランス式変位計により検出した。風速計 と変位計の設置概要も 図一2 に示す.これらの計測は, すべて自動計測システムにより行ったが，2 種類の風速 計のうち, 風車型風向風速計は, 計測時のモニターに使 うとともに自動計測システムのスタータとしても使用し た. 一方, 超音波風速計の記録は, 変位記録とともに磁 気テープに記録した.なお，自動計測システムのスター タとしては，塔頂変位計測用の加速度計を使用した. す なわち，風速もしくは塔頂の加速度が設定した数值以上 になれば, データ・レコーダが 15 分間作動して 1 デー タを記録するシステムとした. 現地観測の期間中に顕著 な振動現象を記録したケースを 表一1 に掲げる.

\section{（3）風観測結果}

a）データ整理方法

磁気テープに 集録された超音波風速計による 測定值 は， 0.04 秒のサンプリング間隔で A/D 変換し,解析に はこのデータ 5 個を平均した值を用いた. したがって, 解析用データのサンプリング 間隔は 0.2 秒である. 各 記録から 10 分間の測定值をとり, これより風速の水平 成分 $U_{H}$, 水平風向角 $\beta_{H}$ の 10 分間平均値 $\bar{U}_{H}$ およ び $\bar{\beta}_{H}$ を求めた. また, 乱れ強さ $I_{U_{H}}$ を $\sigma_{U_{H}} / \bar{U}_{H}$ で定 義して, 同様のデータから求めた. ここに, $\sigma_{U_{H}}$ は $U_{H}$ の 10 分間における標準偏差である. なお, 風向角 $\beta_{H}$ は橋軸方向を $0^{\circ}$ または $360^{\circ}$ と定義している. したが って, $\beta_{H}=90^{\circ}$ および $270^{\circ}$ が橋軸直角方向となる. そ 


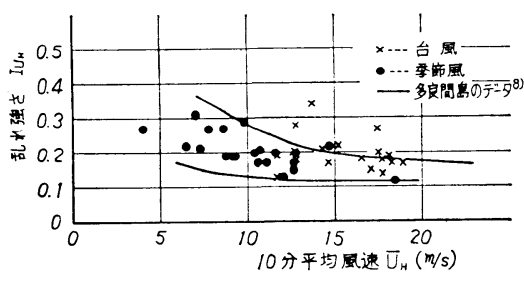

図-3

して,この方位はおおよそ NNW， SSE にあたる.

b） 測定結果とその考察

表一1 に示した RUN 704, 1603 などの台風時のデー タと, RUN 2501, 3408 などの季節風時のデータの中か ら, 渦励振現象に関係すると考えられる平均風向が $\bar{\beta}_{H}$ $=270^{\circ} \pm 20^{\circ}$ の範囲に納まる データを抽出して, 平均風 速 $\bar{U}_{H}$ と乱れ強さ $I_{U_{H}}$ の関係を求めると 図一3 のよ うになる. 図から明らかなように季節風の乱れ強さ $I_{U_{H}}$ は平均風速 $\bar{U}_{H}$ の増加とともにやや低下する傾向がみ られる. 台風時には， $I_{U_{H}}$ のばらつきがやや大きいよう である. 図中に示した 2 本の実線は, 沖縄県多良間島で 数年間にわたって観測された台風時のデータ群多 からそ の範囲を求めたものである. 周辺地形, 測定点高度さら には平均時間などの条件が違うので両者を直接比較する

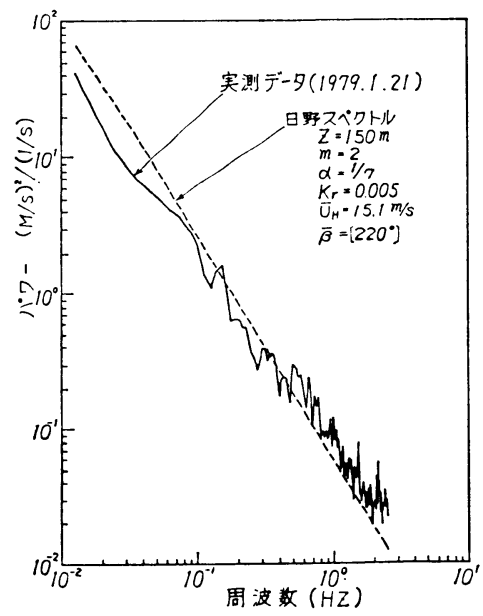

図-4变動風速のパワースペクトル

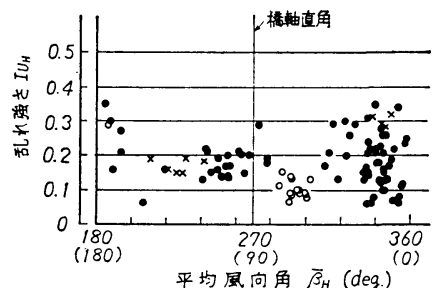

注）×印怡風時のデータ ○印 は $\beta=0 \sim 1800 テ ゙-タ$ $\overline{\mathrm{U}}_{\mathrm{H}}=9 \mathrm{~m} / \mathrm{s} \sim 11 \mathrm{~m} / \mathrm{s}$
ことは必ずしも妥当ではないが，ほぼ同一の傾向を示し ていることが認められるであろう，後述するように，渦 励振の発生風速は $10 \mathrm{~m} / \mathrm{s}$ 前後であったが, 図一2 によ れば,この゙風速付近での $I_{U_{H}}$ は $0.15 \sim 0.30$ 程度とみ ることができる. 図一4 は変動風の周波数領域の特性を 表わすパワースペクトルを求めた一例である. 図中に は，パワースペクトルに関する日野の提案式9によるる值 を破線で示した. 実測結果がこれと同一の傾向であるこ とが明確に認められる. 次に, 図一5 は，風速範囲が $\bar{U}_{H}=9 \mathrm{~m} / \mathrm{s} \sim 11 \mathrm{~m} / \mathrm{s}$ の場合について, 乱れの強さと風 向の関係を求めたものである. この図より，向島と因島 との間の海峡を吹き抜ける風 $\left(\bar{\beta}_{H}=250^{\circ}\right.$ または $70^{\circ}$ 付 近）は乱れがやや小さく, 一方, 向島または因島から吹 く風 $\left(\bar{\beta}_{H}=360^{\circ}\right.$ または $180^{\circ}$ 付近) はやや乱れが大き くなっていることが知られる. 当然のことながら，これ は主塔 $3 \mathrm{P}$ の背後に小山があることなど因島大橋周辺 の地形的条件によるものと考えられる.

\section{（4）振動応答測定結果}

風による振動の測定に先立ち，主塔 $3 \mathrm{P}$ の固有振動特 性を調查した. まず, ウィンチにより制振装置用のワイ ヤロープを主塔の固有周期に合わせて数回巻掲げ巻戻し を行った後現われた自由振動から主塔の無風時の対数減 衰率を求めた. 結果を 表一2 に示す. ただし, この場 合の振動の大きさは, 最大振幅約 $2.5 \mathrm{~mm}$ 程度の微小 なものであった. ちなみに，関門橋の独立主塔に対する 実測值 ${ }^{3}$ はロケットを用いた実験では, 塔頂振幅 $60 \mathrm{~mm}$ 以下の範囲で $\delta=0.0098$, 起振機を用いた実験では，塔 頂振幅 $40 \mathrm{~mm}$ 以下の範囲で $\delta=0.0089$ であり, 今回 得られた数値とほぼ対応している. なお, 面外曲げの最 低次振動数の測定值は，塔頂部にケーブル工事用架設機 材のない独立塔の状態で $0.238 \mathrm{~Hz}$, 架設機材が 取り付 いた状態では $0.223 \mathrm{~Hz}$ であった.

\section{表一2 振幅と対数減衰率の関係}

\begin{tabular}{c|c|c|c|c|c}
\hline 振幅 $(\mathrm{mm})$ & 1.5 & 2.0 & 2.5 & 3.0 & 3.5 \\
実験ケース & & & & & \\
\hline TEST 1 & - & 0.008 & 0.009 & 0.010 & 0.015 \\
TEST 2 & 0.019 & 0.010 & 0.004 & 0.010 & 0.014 \\
\hline
\end{tabular}

（2）で述べたように，風による主塔の振動は，主塔内 6 点で測定したが，塔頂で測定された最大振幅の值を 表一1 に風速・風向とともに示す.これらの振幅がみら れた振動は, 風向や風速の条件から考えて, 台風時のも のを除き渦励振によるものと 推測される. なお，表一1 には，制振装置がセットされていないフリーのケース， スライディング・ブロックの重量 $W$ を $2.25 \mathrm{tf}$ (2.25 t) (以後 $W_{1}$ と称する) としたケースおよび $W=5.58$ tf $\left(5.58 \mathrm{t}\right.$ ) (以後 $W_{2}$ と称する) としたケースの 観測 


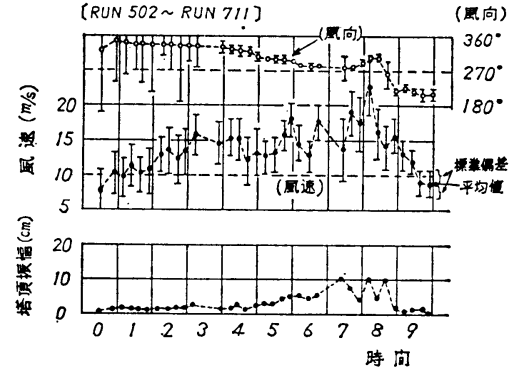

図一6風向・風速と塔頂振幅の関係（台風時）

データが含まれている.

制振装置を設置した方が フリーの場合より最大振 幅が大きくなるケースも みられるが,これは，渦 励振の発達に有効な風 速・風向の持続時間の違 いに起因するものであ る. 表中 RUN 5302 が フリーの状態の最大振幅 を記録したケースで，片 振幅 $77 \mathrm{~cm}$ の渦励振振

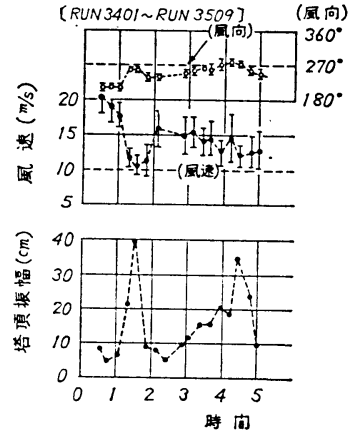

図一7風向・風速と塔頂振幅 の関係 (季節風時)

幅が記録された.これらの記録の中から，振動応答の特 徵を示すために台風 7916 号通過時 (RUN 502〜RUN 711) および季節風時（RUN 3401〜RUN 3509）に得ら れた風向，風速および塔頂振幅の実測記録を図一6およ び 図一7 に示す.ただし，実測された風速範囲では， ねじれ振動成分は微小であって曲げ振動成分が卓越して おり，したがって，図中の振幅は曲げ成分のみを示して いる. 図一6 にみられる振動は, フリー状態であるのに もかかわらず振幅が最大で約 $11 \mathrm{~cm}$ と比較的小さかっ た.このとき, 風向と風速は, 渦励振が発生する条件, すなわち橋軸直角方向の風向と $10 \mathrm{~m} / \mathrm{s}$ 強の風速とはほ とんど合致しておらず，また風速が大きくなれば振幅も 大きくなる傾向を示している. したがって，この振動は 風の変動性が振動を強制するところのいわゆるバフェッ

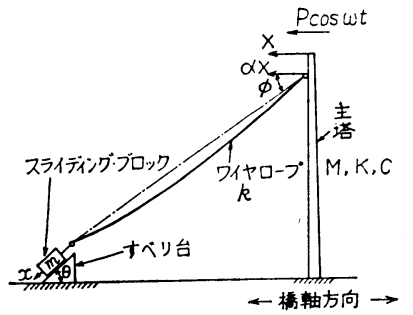

(a)

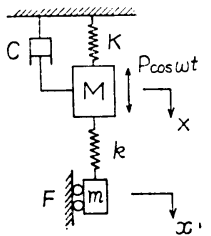

(b)

図一8 主塔一制层装罡の振功系

ティングに属するものとみられる.

これに対して，図一7にみられる振動は，スライディ ング・ブロック $\left(W_{1}\right)$ が設置されているときに現われ たものであるが，風向・風速が前述した渦励振発生の条 件に合致すると振動が大きく誘起される状況がはっきり と認められ，このようなことから, 発生振動は渦励振に 属すると考えられるものである. また，このときにスラ イディング・ブロックの移動む確認されている.

\section{3. 制 振 装置}

\section{（1）制振装置の原理}

主塔 $3 \mathrm{P}$ に用いられたスライディング・ブロックに よる制振装置は，図一8 に示すように，塔自体の構造減 衰にすべり機構による摩擦減衰を付加したものである. 主塔とブロック間のワイヤロープの変形を考慮して, 図 -8(a) の振動系を（b）に示す 2 質点系の振動モデルに 単純化し，一方渦励振の外力を周期的強制外力と考える と, 運動方程式は次のようになる.

$$
\begin{aligned}
& M \ddot{\mathrm{X}}+C \dot{X}+K X+k \alpha\{\alpha X \cos \phi \\
& \quad-x \cos (\theta-\phi)\} \cos \phi=P \cos \omega t \\
& (W / g) \ddot{x}+k\{x \cos (\theta-\phi) \\
& \quad-\alpha X \cos \phi\} \cos (\theta-\phi) \pm F=0
\end{aligned}
$$

ここに,

$M, C, K$ : 主塔の換算質量, 減衰係数, 換算ばね定 数

$\alpha:$ 主塔へのワイヤロープ取付位置の変位と 頂部変位との比

$k:$ ワイヤロープの換算ばね定数

$W:$ スライディング・ブロックの重量

$F:$ ブロックとすべり台の間の摩擦力

$(F=\mu W \cos \theta, \mu:$ 摩擦係数 $)$

$\theta:$ すべり台の傾斜角

$\phi:$ ワイヤロープの両端を結ぶ線と水平線の なす角

$P:$ 換算強制力

$\omega:$ 強制力の円振動数

$X:$ 塔頂の水平変位

$x:$ ブロックのすべり面に沿った変位

式 (1)，(2) の解析解を求めることは 困難であるため, ここでは共振時における外力および減衰力のなす仕事が 等しいという条件から近似解を求めた. この場合, 共振 時における塔頂振幅 $A$ おひびブロック振幅 $a$ は次式で与 えられる。

$$
A=\frac{1}{c\left(2 \pi f_{1}\right)}
$$




$$
\times\left[P-\frac{4 k W \alpha \cos \theta \cdot \cos \phi \cdot \cos (\theta-\phi)}{\pi\left\{k \cos ^{2}(\theta-\phi)-(W / g)\left(2 \pi f_{1}\right)^{2}\right\}} \cdot \mu\right]
$$

$$
a=\frac{k \alpha \cos (\theta-\phi) \cdot \cos \phi}{k \cos ^{2}(\theta-\phi)-(W / g)\left(2 \pi f_{1}\right)^{2}} \cdot A
$$

ここに, $f_{1}$ は連成振動数であり, 式 (1), (2) から導か れる振動数方程式から計算されるが, 実用上 $f_{1}$ は主塔 の固有振動数として扱える.なお，一部のケースについ ては, 式 (1), (2) の直接解をルンゲ・クッタ・ギル法 によって求め式 (3), (4) との対比を行った.

\section{（2）因島大橋主塔（3 P) で採用した制振装置の諸} 元

前項の式 (3), (4) により, 制振装置のブロック重量 $W$ をパラメーターとして, 塔頂振幅と摩擦係数が導か れる. 計算にあたっては次の各数值を用いた. まず, 因 島大橋の主塔諸元から求められる前述の 2 質点モデルの 各係数は,

$$
\begin{aligned}
& M=84.2 \mathrm{tf} \cdot \mathrm{m}^{-1} \cdot \mathrm{s}^{2}\left(0.825 \mathrm{MN} \cdot \mathrm{m}^{-1} \cdot \mathrm{s}^{2}\right) \\
& K=182.0 \mathrm{tf} \cdot \mathrm{m}^{-1}\left(1.784 \mathrm{MN} \cdot \mathrm{m}^{-1}\right) \\
& C=0.394 \mathrm{tf} \cdot \mathrm{m}^{-1} \cdot \mathrm{s}\left(3.86 \mathrm{kN} \cdot \mathrm{m}^{-1} \cdot \mathrm{s}\right)
\end{aligned}
$$

となった. ここに, 固有振動数は $f_{0}=0.234 \mathrm{~Hz}$ （計算 値), 構造対数減衰率は $\delta=0.01$ とした. また, 制振装 置は, 現地の地理的な条件加ら, $\phi=27.6^{\circ}, \theta=45^{\circ}, \alpha \doteqdot$ 1.0 として設置した. 強制外力 $P$ は, 風洞実験で得ら れる塔頂振幅 $A$ およびそのときの構造減衰率 $\delta$ から $P=A \cdot(\delta / \pi) \cdot K$ として求めることとし, 因島大橋主塔 と同様の規模である関門橋の主塔の風洞実験結果 ${ }^{3)}$ に基 ゔいて $P=0.541 \mathrm{tf}(5.30 \mathrm{kN})$ とした. 一方, ワイヤ ロープのばね定数 $k$ は, 図一8 に示すワイヤロープの 取付点に水平力 $H$ が作用したときのロープ弦方向伸び $\Delta l$ を有限変形法より求め $k=H / \Delta l$ として決定したが,

\section{表一3 ワィヤロープのばね定数}

\begin{tabular}{c|c|c|c|c|c}
\hline $\begin{array}{c}\text { スライディッグ・ブ } \\
\text { ロック重量W(tf) }\end{array}$ & 10.0 & 7.5 & 5.0 & 2.5 & 2.25 \\
\hline ばね2定数 $k(\mathrm{tf} / \mathrm{m})$ & 11.308 & 10.920 & 8.010 & 2.329 & 1.817 \\
\hline
\end{tabular}

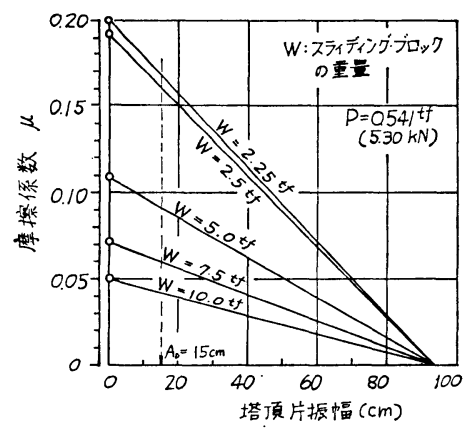

図一9 庵擦係数と塔頂最大振幅の関係

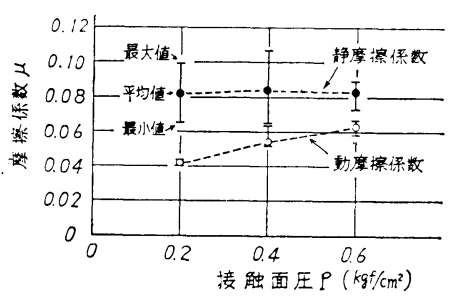

図一10 摩擦係数の測定結果

この值はワイヤロープの初期張力によって変化するた め, ブロック重量 $W$ をパラメーターとすると表一3の ような值となった.

以上の数值を式 (3), (4) に代入し，A〜 〜 の関倸を $W$ をパラメーターとして求めたが, 図一 $\mathbf{9}$ には $A \sim \mu$ の関係を示す.この図から, 塔頂の許容振 幅 $A_{0}$ および摩擦係数 $\mu$ を与えると, スライディング・ ブロックの必要重量 $W$ が決まる. そこで, 許容振幅 $A_{0}$ については, 塔頂での作業性を支配的な 要因として 考え, 振動環境下の作業性に関する ISO の推奖基準 ${ }^{10)}$ を参考にして， $A_{0}=15 \mathrm{~cm}$ とした. 図一9より摩擦係数 が制振効果に大きく影響することが知られるので，摩擦 係数が安定するように, すべり台のレール面にステンレ ス鋼板，スライディング・ブロックの底面にテフロン板 をそれぞれ取り付けることにした.この状態での摩擦係 数については, 別途室内試験を行って確認したが 図一 10 にその結果を示す. なお制振用 ブロックとしては, 内部を 4 室に分割した外側寸法 $1.5 \mathrm{~m} \times 3.0 \mathrm{~m} \times 1.2 \mathrm{~m}$ の鋼製箱を用い, 内部に入る水量を変化させることによ って重量 $W$ が $2.25 \mathrm{tf}(2.25 \mathrm{t}) \sim 10.0 \mathrm{tf}(10.0 \mathrm{t})$ の範 囲で調整できるものとした.

なお，2.(4) で述べたスライディング・ブロックの重 量 $W_{1}(2.25 \mathrm{tf})$ での観測データは, ブロック内に水を 入れない状態に対するものである. 一方, 塔頂振幅を $A_{0}=15 \mathrm{~cm}$ に収めるために必要なブロック重量は, 図一 10 より摩擦係数を $0.07 \sim 0.08$ と見積り，図一9を考慮 すると約 $6 \mathrm{tf}$ となる. $W_{2}(5.58 \mathrm{tf})$ はこの状態に対応 するものである.

\section{（3）制振装置の効果}

主塔の風による振動の測定結果全般を通じて制振装置 の効果が明らかに認められているが，特に，1980 年 3 月 1 日にはその効果を最も具体的に示す結果が得られ た.この日は，橋軸直角方向に $7 \mathrm{~m} / \mathrm{s} \sim 12 \mathrm{~m} / \mathrm{s}$ のかなり 安定した季節風が数時間にわたって吹き，その風によっ て主塔には顕著な渦励振が発達した.このときの記録を 図一11 に示す. ただし, 残念ながら 超音波風速計の故 障のため風の記録は風車型風向風速計によるものであ る. 図中に示されているように, 主塔は前半はフリー状 


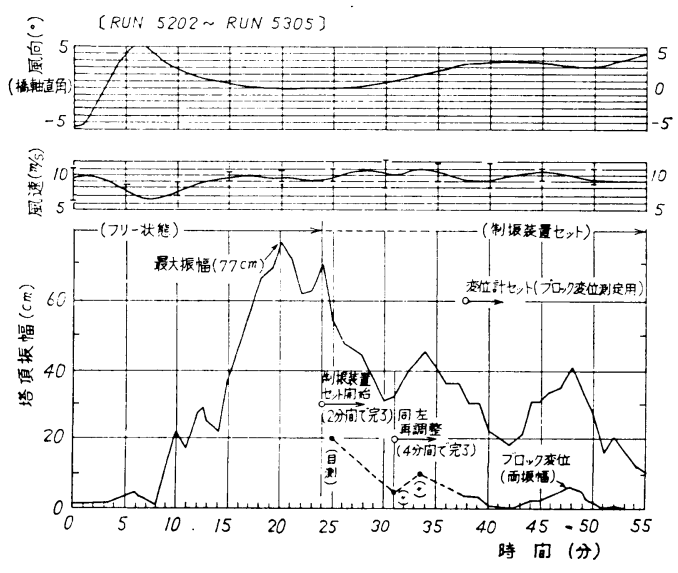

図一11 風向・風速と塔頂振幅の関係

態で，また後半は，制振装置が $W=W_{1}$ としてセット された状態にあった. そして, フリー状態のときに, 風 向が橋軸直角方向で風速が $9 \mathrm{~m} / \mathrm{s} \sim 11 \mathrm{~m} / \mathrm{s}$ の風が約 10 分程度持続した 時点で振幅は $77 \mathrm{~cm}$ まで発達したので ある.ここでただちに制振装置を $W=W_{1}$ としてセッ トすると, 図一11 より明らかなように制振装置が勃果 を発揮し, 振幅が減少してその後に現われた塔頂最大振 幅は約 $40 \mathrm{~cm}$ にとどまった. なお，スライディング・ ブロックの周期的な動きも確認されたが，これを塔頂の 運動と合わせて 図一12 に示す. 図一12 には, $W=W_{2}$ の場合（RUN 5403）についても示してある.これより $W=W_{1}$ では塔頂振幅が約 $20 \mathrm{~cm}$ を越えるとブロック が動き始めるのに対し， $W=W_{2}$ では塔頂振幅が約 10

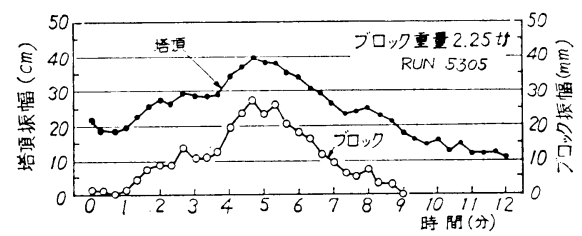

(a)

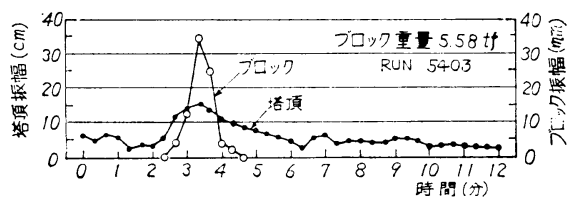

(b)

図一12 塔頂振幅とブロック振幅の関係 cm でブロックが運動を始めることが認められる.ここ で，3. (1) に述べた式 (3)，(4) から塔頂振幅 $A$ および ブロック振幅 $a$ を求め, 測定值と対比すると表一4 のよ うになる. この場合, 主塔諸元としては, 塔頂部にケー ブル工事用足場等の機材が取り付いた状態が対象となる ため, 3. (2) で用いたものとは異なり以下の数值である. $M=95.9 \mathrm{tf} \cdot \mathrm{m}^{-1} \cdot \mathrm{s}^{2}\left(0.940 \mathrm{MN} \cdot \mathrm{m}^{-1} \cdot \mathrm{s}^{2}\right), C=0.428 \mathrm{tf} \cdot$ $\mathrm{m}^{-1} \cdot \mathrm{s}\left(4.19 \mathrm{kN} \cdot \mathrm{m}^{-1} \cdot \mathrm{s}\right), K=188.3 \mathrm{tf} \cdot \mathrm{m}^{-1}(1.845 \mathrm{MN}$. $\left.\mathrm{m}^{-1}\right), f_{0}=0.223 \mathrm{~Hz}$ ，また， $W=W_{2}$ に対する $k$ の值 は 表一3 より内插して 推定して $k=8.69 \mathrm{tf} \cdot \mathrm{m}^{-1}(85.2$ $\left.\mathrm{kN} \cdot \mathrm{m}^{-1}\right)$ とした. 空気力 $P$ については,フリー状態の 塔で観測した最大振幅 $77 \mathrm{~cm}$ に対応する強制空気力が 作用したものと仮定した. このとき $P=0.462 \mathrm{tf}(4.53$ $\mathrm{kN})$ となる. さらに摩擦係数は $\mu=0.07$ と見積ってい る. 表一4 において, $W=W_{2}$ のケースについては,ル ンゲ・クッタ・ギル法によって式 (1)，(2) の直接解を 求めた結果を併記した. 表一 4 より, 計算值は観測值に 一応近い值を示すもののな怙若干の差があり，特にブロ ック振幅において差が著しいことが知られる.これは, 作用空気力 $P$, 主塔の大振幅での構造減衰 $\delta$, 摩擦係数 $\mu$ などの見積りに誤差が含まれているためと考えられる が，特にブロック振幅の観測值が計算值に比べてかなり 小さくなったのは, ロープの減衰・振動モード等の動特 性を無視したことが主要因と考えられる. しかし, 前記 諸数值の正確な推定は困難でありまた, 実用的見地から すれば式 (3)，(4) により，因島大橋主塔の制振装置の 諸元を決定してもおおむね有効であるといって差し支え ないであろう.

\section{4. 風洞実験概要}

前述した現地の各種計測と並行して, 本研究では因島 大橋主塔の $1 / 100$ 縮尺模型による風洞実験を実施した. その際, 通常の一様流による実験のほかに乱流格子によ る一様分布の乱流のもとでの実験を行った.これらは, 2.に述べた実構造物の自然風のもとでの挙動と風洞実 験結果の関連性を検討するために行ったものである.

\section{（1）風洞実験要領}

a）風洞

表一4 制振効果の比較 ( $W=W_{2}$ の場合)

\begin{tabular}{|c|c|c|c|c|}
\hline & \multirow{2}{*}{$\begin{array}{l}\text { 観 側 } \\
(\mathrm{cm})\end{array}$} & \multicolumn{2}{|c|}{ 計 算 值 $(\mathrm{cm})$} & \multirow{2}{*}{ 備 } \\
\hline & & 簡 易 式 & R.K.G. ** & \\
\hline $\begin{array}{l}\text { 塔 頂 振 幅 } A(\mathrm{~cm}) \\
\text { ブロック振幅 } a(\mathrm{~cm}) \\
\text { プロックか動き始める } \\
\text { ときの塔頂振幅、 }(\mathrm{cm})\end{array}$ & $\begin{array}{rc}16.4 & {[43.0]^{*}} \\
3.5 & {[2.8]} \\
10 & {[20]}\end{array}$ & $\begin{array}{l}16.4[47.5]^{*} \\
17.0[59.4] \\
\end{array}$ & $\begin{array}{r}14.8 \\
14.8 \\
4.5\end{array}$ & $\begin{array}{l}\text { * [ ] 内 内の数値は } W=W_{1} \text { の場合を示す. } \\
\text { ** 式 }(1),(2) \text { の直接解をルンゲ・クッタ・ギル法で } \\
\text { 求めたもの }\end{array}$ \\
\hline
\end{tabular}


使用した風洞は，日立造船（株）技術研 究所の水平循環式低速風洞である. 試験で は，風洞測定部を開放型として使用した. この場合, 測定部の長さは $3.9 \mathrm{~m}$ で, 吹出 口の寸法は高さ $2.5 \mathrm{~m}$, 幅 $2.0 \mathrm{~m}$ である. b) 模 型

模型は，風洞の諸元を考慮して縮尺を 1/100 とし，全体を剛に作りそれを弾性支 持することとした. 実塔で観測された曲げ 渦励振の確認を主体として実験を進めた が，より高風速時に発生が予想されるねじ れ振動の特性も明らかにするため曲げ振動 のほかにねじれ振動も生じ得る 2 自由度振 動系となるように模型を支持した. 模型の 設置要領を 図一13 に示す. 模型は風洞測 定部の上方に設置した地面板の位 置か らピアノ線で上下逆に吊り下げ，塔頂部 に4本のばねを取り付けて模型に所定の 振動数を与えた. また塔基部にも補助的 なばねを取り付けて，ねじれ振動数の調 整を行うようにした. したがって，曲げ 振動を塔基部の固定点まわりのロッキン グ振動で，またねじれ振動を中心軸まわ りの回転振動で置き換えたことになる.

表一5 に模型系の振動特性を示す.ねじれと曲げの振動 数比 $N_{T} / N_{B}$ が所要値より低いが, 実験中に発生した曲 げとねじれの振動現象は分離しており，この不一致によ る影響は少ないと考えられる.

\section{c) 気 流}

従来, 構造物の風洞実験では多くの場合一様流によっ て実施されてきたししかし，吊橋主塔に作用する自然風 は，平均風速が高さによって異なったり，風速や風向が 時間的にも空間的にも変動している. したがって，一様 流の風洞実験で測定される振動現象と自然風下での実構 造物の振動現象の間には差異が生じると考えられるが,

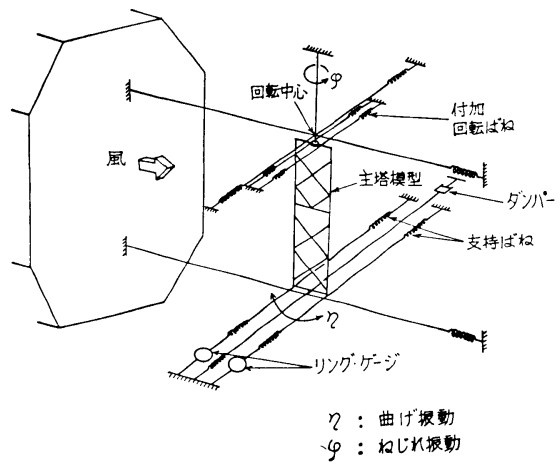

図一13 模型支持の状況
表一5 模 型 の 振動 特 性

\begin{tabular}{|c|c|c|c|c|c|}
\hline & \multirow{2}{*}{ 単 位 } & \multirow{2}{*}{ 所 要 值 } & 測 & 值 & \multirow{2}{*}{ 備 } \\
\hline & & & 一様 流 & 流 & \\
\hline$I_{B}$ & \multirow{2}{*}{$\begin{array}{l}\mathrm{kgf} \cdot \mathrm{cm} \cdot \mathrm{s}^{2} \\
\mathrm{kgf} \cdot \mathrm{cm} \cdot \mathrm{s}^{2}\end{array}$} & 20.547 & 20.52 & 20.81 & \multirow{7}{*}{$\begin{array}{l} \pm 3 \mathrm{~mm} \text { 付近での值 } \\
\pm 0.5^{\circ} \text { 付近での值 }\end{array}$} \\
\hline$I_{T}$ & & 0.539 & 0.534 & 0.534 & \\
\hline$\delta_{B}$ & $\longrightarrow$ & 0.01 & 0.01 & 0.01 & \\
\hline$\delta_{T}$ & - & 0.01 & $0.014 \sim 0.018$ & $0.013 \sim 0.014$ & \\
\hline$N_{B}$ & $\mathrm{~Hz}$ & $\longrightarrow$ & 3.37 & 3.45 & \\
\hline$N_{T}$ & $\mathrm{~Hz}$ & - & $0.09 \sim 6.10$ & $7.42 \sim 7.46$ & \\
\hline$N_{T} / N_{B}$ & $\longrightarrow$ & 3.47 & 1.81 & $2.15 \sim 2.16$ & \\
\hline 䖝速倍率* & - & - & 6.62 & $6.46 \sim 6.47$ & （曲げ摂動） \\
\hline & & & $12.70 \sim 12.73$ & $10.39 \sim 10.45$ & (放じれ振動) \\
\hline
\end{tabular}

風洞風速を実橋風速に換算する保数

$I_{T}:$ 質量極惯性モーメント

$\delta_{B}:$ 曲げ振動構造減衰 (対数隇衰率)

$\delta_{T}:$ ねじれ振動構造減衰 (対数減衰率)

$N_{B}:$ 曲げ振動数

$N_{T}:$ 枟じれ振動数

表一6 格子乱流の乱れ強さおよび乱れスケール

\begin{tabular}{|c|c|c|c|c|c|c|}
\hline \multirow{2}{*}{$\begin{array}{l}\text { 格子の } \\
\text { 名 称 }\end{array}$} & \multicolumn{3}{|c|}{ 格子サイズ*) } & \multirow{2}{*}{$\begin{array}{c}\text { 乱れ強さ } \\
(\%)\end{array}$} & \multirow{2}{*}{ 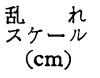 } & \multirow{2}{*}{ 備 } \\
\hline & $d(\mathrm{~cm})$ & $l(\mathrm{~cm})$ & $L(\mathrm{~cm})$ & & & \\
\hline GRID-A & 12 & 48 & 180 & 30 & $1.1 \sim 2.4$ & \\
\hline GRID-B & 6 & 36 & 180 & 19 & $0.5 \sim 2.7$ & \\
\hline GRID-C & 4.5 & 36 & 180 & 16 & $2 \sim 2.3$ & {[} \\
\hline GRID-D & 3.5 & 36 & 180 & 11 & $1.3 \sim 2.9$ & \\
\hline GRID-E & 3 & 36 & 180 & 10 & $1.1 \sim 3.8$ & $\Rightarrow$ \\
\hline GRID-F & 3.5 & 48 & 220 & 8 & $1.5 \sim 2.6$ & L：格子から模型までの距離 \\
\hline
\end{tabular}

平均風速 $2 \mathrm{~m} / \mathrm{s}$ での計测值（主流方向）

風洞実験において，自然風を精密にシミュレートする方 法はまだ一般的に得られておらずこれまでのところ各風 洞で試行錯誤的にいろいろと工夫が試みられているよう である.

以上のような背景を考虑して，本研究では一様流によ る風洞実験をまず実施し，次いで風洞内で自然風をシミ ニレートする試験の采口として, 自然風のもつ各種要因 のうち風速の乱れ強さのみに着目した実験を行った. 乱 流を発生するのには，これまでに実績のある乱流格子を 前面に設置する方法 ${ }^{11), 12)}$ を採用した. 格子の寸法は 表 一6 に示すとおりであり，格子を形成する部材の幅およ び設置間隔を変えることによって乱れの強さを変化させ た. 風洞設備の関係で格子を模型から大きく離すことが できなかったが 表一6 に示した距離でも乱れ特性の分布 の一様性は，GRID-A の場合を除きほぼ保たれたこと が風速測定の結果より見出されている. 表中に示した乱 れ強さや流れ方向の積分スケールは模型位置での值であ るが，現地での風観測結果によると，乱れのスケールは $100 \mathrm{~m}$ 前後であり, したがって風洞気流の乱れスケール については相似性がよくないことを指摘しておきたい。

\section{d） 実験の種類と測定要領}

橋軸直角方向からの風の水平偏角を $\beta$ と定義し, 一 様流では $\beta=0^{\circ}, 5^{\circ}, 10^{\circ}$, 乱流では $\beta=0^{\circ}$ について実験 
を行った. 模型の動的応答変位は, 塔 頂部のばね固定部に設置したリング・ ゲージによって検出し，データ・レコ ーダおよびペン・レコーダに記録した。 平均風速の測定は, 風洞吹出口に設置 したピトー静圧管および熱線風速計を 併用した. また変動風速の測定は， 2 成分 (X 型プローブ) の熱線風速計 を模型位置での断面内または風路中心 軸上を流れ方向にトラバースさせて行 った.

\section{（2） 風洞実験結果およびその考察}

a）一様流の結果

実験結果のうち水平偏角 $\beta=0^{\circ}, 10^{\circ}$ の場合について風速 $U_{H}$ （実橋換算 値) 々塔頂曲げ振幅 $A$ (実橋換算値) およびねじれ振幅 $\varphi$ (模型全高にわた って一定であるので実塔の場合と若干 異なる．以下，ねじれについては参考 データとして示すものである.) の関 係を図一14 に示す. 図一14 から明ら かなように，まず $U_{H}=7 \mathrm{~m} / \mathrm{s}$ 付近で 振幅 $10 \sim 20 \mathrm{~cm}$ 程度の曲げ振動の第 1 ピークが現われる.ただし，この振 動は $\beta=0^{\circ}$ では模型静止状態からは 発振せず，初期の微小かく乱により発 振した.引き続き, $U_{H}=9 \mathrm{~m} / \mathrm{s} \sim 13$ $\mathrm{m} / \mathrm{s}$ で大振幅の曲げ振動第 2 ピークが 生じており， $\beta=0^{\circ}$ の場合には $157 \mathrm{~cm}$ にも達してい る。さらに風速が 上昇するとねじれ振動が生じ， $U_{H}=$ $25 \mathrm{~m} / \mathrm{s} \sim 35 \mathrm{~m} / \mathrm{s}$ で第 1 ピークが,続いて $U_{H}=40 \mathrm{~m} / \mathrm{s} \sim 45$ $\mathrm{m} / \mathrm{s}$ で第 2 ピークが現われた.なお， $\beta=0^{\circ}$ に対するス トローハル数 $S=f_{s} \cdot D / U$ を別途計測したところ $S=$ 0.104 であった. ここに, $f_{s}$ は後流の卓越周波数, $D$ は模型代表長で，塔柱の $70 \%$ 高さでの橋軸方向の幅, $U$ は風洞風速である. 図一14 にはストローハル数 $S$ か ら決まる共振風速 $U_{c r}=N_{B} D / S$ および $1 / 2 U_{c r}$ の位置 をり印で示したが第 2 ピークおよび第 1 ピークの発提風 速がほぼこれらに対応している. またねじれ振動に関し ては $U_{c r}\left(U_{c r}=N_{T} D / S\right)$ および $2 / 3 U_{c r}$ (図中马印で 示す）が扔のおの第 2 ピーク，第 1 ピークの発振 風速 に対応するようであり，文献 13）の指摘と一致してい る.

\section{b）乱流の結果}

GRID-B，GRID-C の場合にみられた風速 $U_{\boldsymbol{H}}$ と塔 頂振幅 $A$ の関係を 図一15 に示す. 乱れがある 場合に

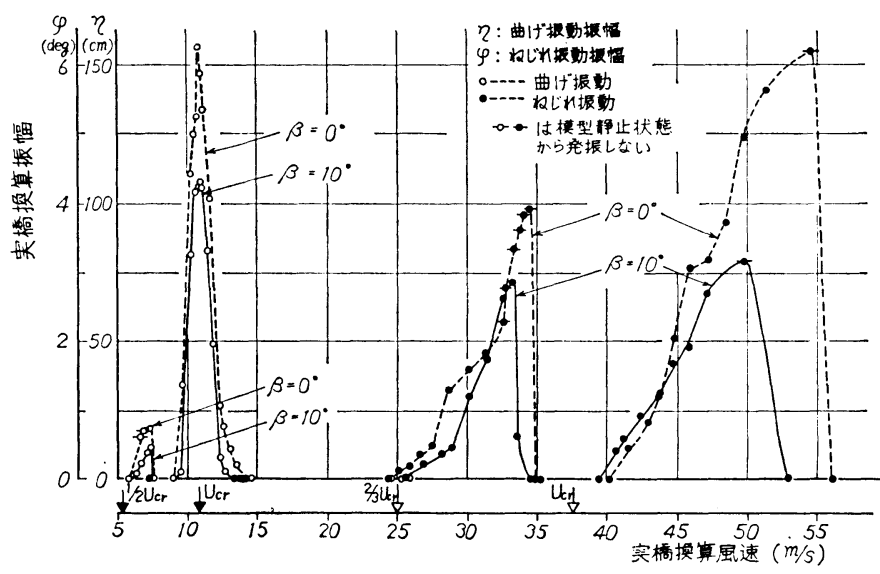

図-14 風速と振幅の関係（一様流）

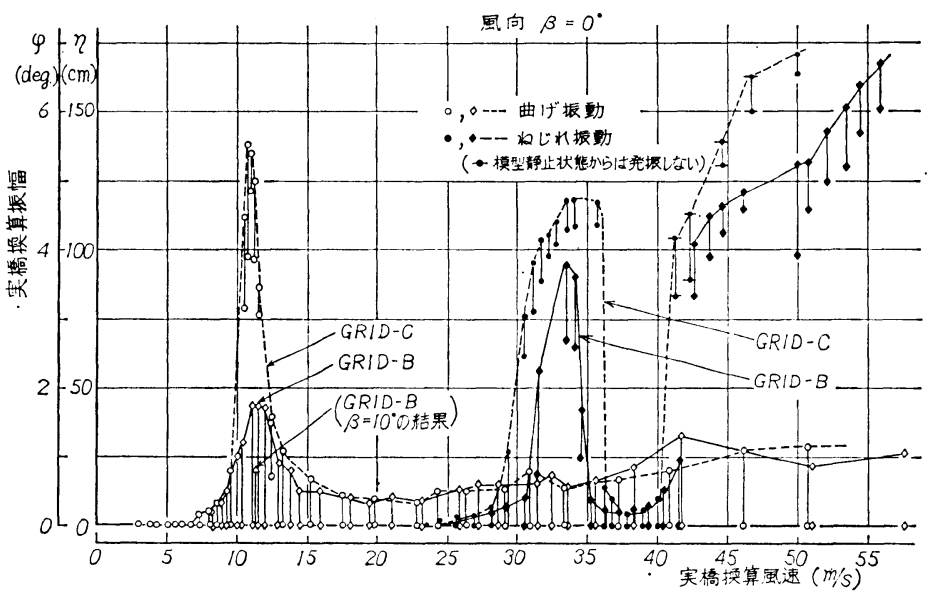

図一15 風速と振幅の関係（乱流）

は，定常状態においても振幅は一般にかなり変動する。 したがって,ここでは記録波形の最大・最小振幅を読み 取ってプロットした．乱流の場合には一様流の場合にみ られた曲げ振動の第 1 ピークは生じていない，また，渦 励振現象の発生風速域が広くなること, 高風速域で曲げ の不規則振動が残ることなどの特徵が指摘できる. 図示 していないが，乱れ強さの最も大きい GRID-A の場合 には，曲げ，ねじれとも渦励振現象はみられず，風速の 上昇とともに不規則振動が増大した. また，GRID-D， $\mathrm{E}, \mathrm{F}$ の応答は 図一15 と同様の傾向であるがピーク点 付近での振幅の変動は 図一15 の場合よりいくぶん小さ いものであった.

\section{5. 風洞実験結果と現地計測結果の関係}

\section{（1）風速と振幅の関係}

風洞実験結果と現地計測結果を比較するために, 両者 


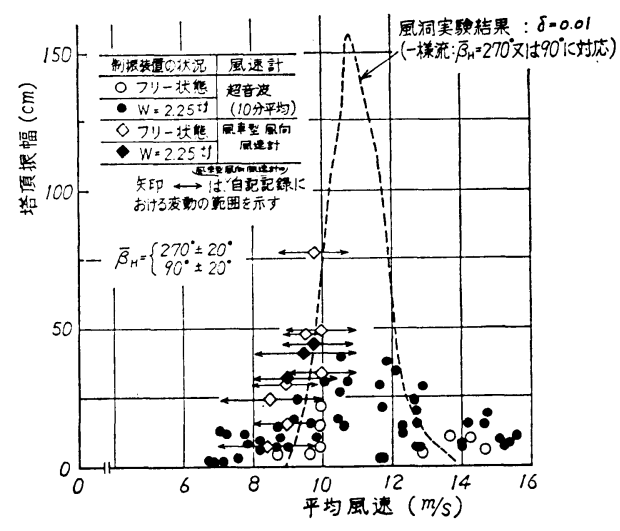

図-16 風洞実験と実橋での観測結果の比較

における塔頂振幅と風速の関係を 図一16 に示した.こ こで, 現地計測の值は, 平均風向 $\bar{\beta}_{H}$ が橋軸直角方向か ら $\pm 20^{\circ}$ の範囲のデータから求めたものである. 図中,

$\diamond, \diamond$ 印のデータは, 超音波風速計が故障のため風車型 風向風速計の自記記録（送り速度が遅いので変動状況の 詳細は不明であった）から目測で平均風速および最大・ 最小風速を読み取りその範囲を矢印で示している，ま た，制振装置を $W=W_{1}$ としてセットした状態のもの （図中○印または・印で示す）および，制振装置をセ ットしていないフリー状態のもの（図中○印またはつ印 で示す）両者の值を示した. 制振装置のある場合の方が フリーの場合より振幅が大きくなるケースもみられる が，これは渦励振を誘起する風向・風速の作用時間が異 なっていたことによると考えられる. 一方, 一様流での 風洞実験の結果を 図一16 では点線で併記した. 図一16 より，フリー状態の実塔で測定された塔頂の最大振幅は 一様流の風洞実験で測定された最大振幅の約 $1 / 2$ であっ たことが知られる. しかし，風速と振幅の関係全体をみ ると現地実測值と風洞実験値はフリー状態の場合にわり あいよく一致しているようにみることができる．なお， 現地計測では平均風速が $25 \mathrm{~m} / \mathrm{s}$ 以上となることはな く，風洞実験でみられたねじれ振動は観測されなかっ た.

\section{（2） 風速の乱れ強さと振幅の関係}

乱流による風洞実験で得られた曲げ振動のピーク值と 乱れ強さの関係を 図一17 に示す. 図中には, 現地観測 值も記入したが，この值は $\bar{\beta}_{H}$ が橋軸值角から $\pm 10^{\circ}$ か つ $\bar{U}_{H}$ が $9 \mathrm{~m} / \mathrm{s} \sim 12 \mathrm{~m} / \mathrm{s}$ のもので, 風速計の記録より 乱れ強さが計算できた場合のデータである. したがっ て，フリー状態の現地観測值はないが，フリー状態で得 られた最大振幅 $(77 \mathrm{~cm})$ の場合についてのみ, 風の条 件が類似のデータから乱れ強さを推定して矢印でその範 囲を示した. 図一17 から風洞実験值では乱れ強さ $I_{U_{H}}$

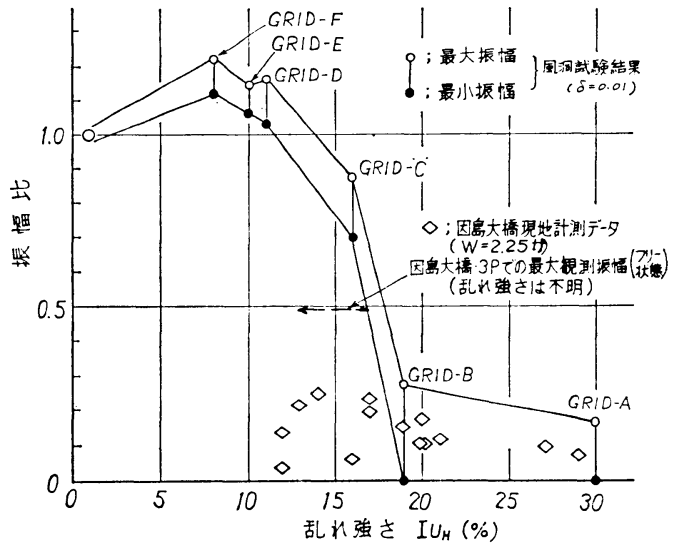

図一17乱れ強さと渦励振振幅の関係

が 10\% から 20\% の範囲で渦励振振幅が顕著に低下す る傾向にあることがわかるので，乱れ強さも自然風下で の渦励振現象に影響を与える要因の一つであることがう かがえる.

\section{（3）風向と振幅の関係}

現地計測データから平均風速が $9 \mathrm{~m} / \mathrm{s} \sim 12 \mathrm{~m} / \mathrm{s}$ のデー タを抽出して，風向と塔頂振幅の関係で整理したものが 図一18 である. 図中に点線で, 一様流での風洞実験值 を示した. この図より，現地観測值と風洞実験值の両者 において風向が橋軸直角からほぼ $\pm 10^{\circ}$ の範囲で曲げの 渦励振が発達する状況がわかる. また， $\pm 20^{\circ}$ 付近にな ると渦励振の規模はきわめて小さくなっている. このよ うなことから，因島大橋主塔の場合曲げ渦励振現象につ いては, 橋軸直角方向から $\pm 10^{\circ}$ 以内の風向の風が問題 になるものと推定される.

\section{（4）まと め}

以上, 風洞実験值と現地計測値を風速と振幅, 乱れ強 さと振幅, および風向と振幅の関係において比較した結 果を示した. これらによって, 少なくとも定性的には両 者が同じ傾向を示していることが見出される．したがっ

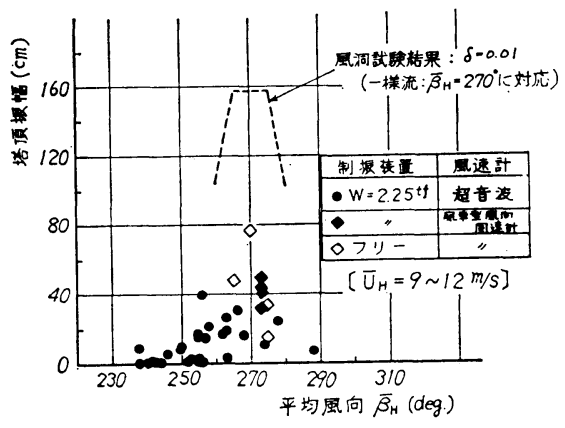

図一18 平均風向と応答振幅の関係 
て風洞実験によって実物の挙動を, 特に渦励振に関して は一応の精度をもって推測できるといって差し支えない ように考えられる. しかしながら，本研究では，風洞実 験值と現地計測值が定量的にも一致をみせるまでには至 らなかった，そのおむな理由としては，現地における風 向と風速の状態が振幅の最大值をもたらす条件に完全に は達しなかったことや，風洞実験における気流が現地の 自然風の状態を十分には相似していないことが挙げられ る. 塔状構造物の自然風による振動の解析法について は, すでに Vickery ${ }^{14), 15)}$ や Davenport ${ }^{16)}$ らの研究が あり，また風洞実験や実物観測の 報告もみられている が，実塔の挙動をより精密に推定する方法を確立するた めには，これらの研究成果を含めて，今後なお多くの検 討資料の集積が必要であるように考えられる.

\section{6. 結言}

本研究では，独立状態の因島大橋主塔（3P）の風に よる振動現象と風自体の現地計測，ならびに同主塔の縮 尺模型による風洞実験を実施した. また，著者らが利用 したスライディング・ブロック方式の制振装置につい て，その効果を確認した. これらを要約すると以下のよ うになる.

（1）現地計測を実施した結果，制振装置を設置した 状態やフリーの状態で, 主塔の渦励振現象に関するデー 夕を得ることができた. この渦励振は 10 分平均風速が $9 \mathrm{~m} / \mathrm{s} \sim 12 \mathrm{~m} / \mathrm{s}$ で，風向が橋軸直角方向から $\pm 10^{\circ}$ の範 囲の場合に出現した. この風向と風速の組合せの関係か ら，台風時より比較的安定した風が吹く冬期季節風時に 渦励振の発生頻度が高かった．また，現地計測で得た曲 げ渦励振現象の最大振幅は，塔頂で $77 \mathrm{~cm}$ であった. なお，平均風速が $25 \mathrm{~m} / \mathrm{s}$ 以上になったことがなく、ね ビれの顕著な振動現象はみられなかった。

（2）スライディング・ブロック方式による制振装置 は，有効に作動することが実物の観測で確認できた．特 に, フリー状態で振幅 $77 \mathrm{~cm}$ にまで発達した渦励振が, 制振装置を取り付けた直後には振幅 $40 \mathrm{~cm}$ に低減した ことで効果が明膫に見出された．著者らは制振装置の効 果を計算する簡易式を導いたが，因島大橋主塔に対して は，この式による制振装置はおおむね妥当であった.

（3）一様流および格子乱流による風洞実験において も，実塔でみられた渦励振現象が同様に出現した。この 現象に関して, 風速と振幅, 乱れ強さと振幅および風向 と振幅の関倸につき風洞実駼值と現地実測值の両者を比 較したところ，定性的には同一の傾向にあることがわか った. しかし，定量的一致をみるまでに至らず，今後の 研究の余地を残した.
因島大橋主塔の架設時における耐風性の判断には土木 学会本州四国連絡橋耐風研究小委員会の委員各位にいろ いろとご助言をいただいた. さらに，本論文のとりまと めについては, 中央大学 岡内 功教授のご援助を賜わ った.ここに深甚の謝意を表するものである．また，本 研究実施に多大の便宜をはかっていただいた竹内覚夫氏 （本州四国連絡橋公団第二建設局児島工事事務所）およ び池田 博氏（同第三建設局向島工事事務所）の各位に 感謝の意を表します.なお，現地計測に関しては牧本 宏氏（日立造船（株）技術研究所），風洞実験に関しては 田中 洋氏（日立造船（株）陸機設計所）の協力があっ たことを記し感謝します.

\section{参 考 文 献}

1) Anderson, J.K. : Forth Road Bridge, Proc. Institution of Civil Engineer, Vol. 32, 1965.

2) Scruton, C. and D.E. Walshe : An Investigation of the Aerodynamic Stability of Towers Proposed for the River Severn Suspension Bridge, N.P.L. Aero Report 1052, 1963.

3）建設省土木研究所 : 関門橋設計施工調查報告書, 土研資 料 825 号, 1973 .

4）牛尾・植田・南條：つり橋主塔の 制振対策の一試案につ いて，日立造船技報，Vol. 32，No. 3，1971。

5）辻・加納・渡辺：吊橋主塔架設時の耐風制振法，日本鋼 管技報, No. 82, 1979 .

6）松崎・竹内 - 砂原・辻・加納：吊橋主塔架設時の耐風制 振対策，第 6 回風工学シンポジウム論文集，1980.

7）土木学会・本州四国連絡橋耐風研究小委員会, 本州四国 連絡橋の耐風に関する調査研究報告書, 昭和 55 年 3 月抢 よび昭和 56 年 3 月.

8）台風研究委員会：多良間島における 台風観測研究・総合 報告書, 1980 .

9） 日野幹雄 : 瞬間最大值と評価時間の関係一特に 突風率に ついて, 土木学会論文集, No. 117, 1965.

10) ISO-2631 (1974) Guide for the Evaluation of Human Exposure to Wholebody Vibration.

11）白石成人：変動風をらける平板状構造物の耐風态答特性 に関する 2,3 の基礎的研究，土木学会論文報告集，No. 195 号, 1971.

12）東京大学工学部土木工学科橋梁研究室, 本州四国連絡橋 公団受託研究・併用吊形式橋梁等の 耐風性に関する 研究・ 昭和 48 年度報告, 東京大学橋梁研究室報告 BEL-Report No. $74201,1974$.

13）京都大学工学部土木工学教室・橋梁工学研究室：吊橋の 耐風安定性に関する調查研究，昭和 55 年度本州四国連絡 橋公団委託研究・研究成果報告書, 1981 .

14) Vickery, B.J. and A.W. Clark : Lift or Across-Wind Response of Tapered Stacks, Proc. ASCE, ST-1, 1972.

15) Vickery, B.J. : A Model for Prediction of the Response of Chimneys to Vortex Shedding, Technische Mitteilungen, 72 Jahrgang, Heft 2/3/4, Februar/März/ April, 1979.

16) Davenport, A.G. : The Response of Suspension Bridges to Wind Action, International Research Seminar on Safty of Structures under Dynamic Loading, Trondheim, 1977.

(1982.7.22 • 受付) 